\title{
INNOVATION IN PUBLIC POLICIES: A BIBLIOMETRIC STUDY FOR NEW RESEARCH
}

\author{
INOVAÇÃO EM POLÍTICAS PÚBLICAS: UM ESTUDO BIBLIOMÉTRICO PARA NOVAS PESQUISAS
}

INNOVACIÓN EN POLÍTICAS PÚBLICAS: UN ESTUDIO BIBLIOMÉTRICO PARA NUEVAS INVESTIGACIONES

\author{
Samara de Carvalho Pedro ${ }^{1}$ \\ Fernanda Edileuza Riccomini de Souza ${ }^{2}$ \\ (iD) Daniela Menezes Garzaro ${ }^{3}$ \\ (iD Claudia Brito Silva Cirani ${ }^{4}$ \\ Maria Tereza Saraiva de Souza ${ }^{5}$
}

Cite as - American Psychological Association (APA)

Pedro, S. de C., Souza, F. E. R., Garzaro, D. M., Cirani, C. B. S., \& Souza, M. T. S. (2021, Sept./Dec.). Innovation in public policies: a bibliometric study for new research. International Journal of Innovation - IJI, São Paulo, 9(3), 496-521. https://doi.org/10.5585/iji.v9i3.19676.

\begin{abstract}
Objective: To carry out a mapping of studies on innovation and public policies, presenting an overview of the scientific discussion on the topic to suggest proposals for future studies.

Design / methodology / approach: A bibliometric study, through exploratory factor analysis, with the objective of identifying the path that the phenomenon takes. For this, we use the techniques of citation, co-citation and bibliographic coupling.

Originality: Given the economic, social and technological importance of innovation, public policies appear as engines of the development of innovation, thus reinforcing the need to identify unexplored paths through the mapping of studies on the theme to identify unexplored paths.

Results: We identified the basis on which the theme studied was developed. Thus, three factors were observed: Economic Development, Innovation Ecosystems and State Participation. In the coupling analysis, we identified four factors, namely: Entrepreneurship, Changes in Public Policies, Networks and Clusters and Knowledge Source. Looking to the future, some study trends were presented, highlighting a new research agenda.

Theoretical and methodological contributions: We present some study trends on innovation and public policies, warranting a new research agenda.

Management contributions: This research enables managers and decision makers to understand the aspects regarding the theme, so that they can develop strategic innovation actions with the support of public policies.
\end{abstract}

Keywords: Innovation. Public policy. Innovation environment. Innovation management. Bibliometrics.

\footnotetext{
${ }^{1}$ Master and PhD in Business student, Centro Universitário FEI. São Paulo - SP, Brasil. samara.c.pedro@ gmail.com

2 Master and PhD in Business student, Universidade Nove de Julho. São Paulo - SP, Brasil. fernanda.riccomini@ gmail.com

3 Master and PhD in Business student, Universidade Nove de Julho. São Paulo - SP, Brasil. garzaro.daniela@ gmail.com

${ }^{4} \mathrm{PhD}$ in Applied Economics, Universidade Nove de Julho. São Paulo - SP, Brasil. claudiabscirani@ gmail.com

5 PhD in Business, Centro Universitário FEI. São Paulo, SP - Brasil. mtereza@ fei.edu.br
} 


\section{Resumo}

Objetivo: Realizar um mapeamento de estudos sobre inovação e políticas públicas, apresentando um panorama da discussão científica sobre o tema para sugerir propostas de estudos futuros.

Desenho / metodologia / abordagem: Estudo bibliométrico, por meio de análise fatorial exploratória, com o objetivo de identificar o caminho que o fenômeno percorre. Para isso, utilizamos as técnicas de citação, cocitação e pareamento bibliográfico.

Originalidade: Dada a importância econômica, social e tecnológica da inovação, as políticas públicas aparecem como motores do desenvolvimento da inovação, reforçando assim a necessidade de identificar caminhos inexplorados por meio do mapeamento de estudos sobre o tema para identificar caminhos inexplorados.

Resultados: Identificamos as bases sobre as quais o tema estudado foi desenvolvido. Assim, três fatores foram observados: Desenvolvimento Econômico, Ecossistemas de Inovação e Participação do Estado. $\mathrm{Na}$ análise de pareamento, identificamos quatro fatores, a saber: Empreendedorismo, Mudanças nas Políticas Públicas, Redes e Clusters e Fonte de Conhecimento. Olhando para o futuro, algumas tendências de estudos foram apresentadas, destacando uma nova agenda de pesquisa.

Contribuições teórico-metodológicas: Foram apresentadas algumas tendências de estudos sobre inovação e políticas públicas, garantindo uma nova agenda de pesquisa.

Contribuições para gestão: Esta pesquisa permite que gestores e tomadores de decisão compreendam os aspectos que envolvem o tema, para que possam desenvolver ações estratégicas de inovação com o apoio de políticas públicas.

Palavras-chave: Inovação. Políticas públicas. Ambiente de inovação. Gestão da inovação. Bibliometria.

\section{Resumen}

Objetivo: realizar un mapeo de estudios sobre innovación y políticas públicas, presentando un panorama de la discusión científica sobre el tema para sugerir propuestas para estudios futuros.

Diseño / metodología / enfoque: Estudio bibliométrico, mediante análisis factorial exploratorio, con el objetivo de identificar el camino que toma el fenómeno. Para ello utilizamos las técnicas de citación, co-cita y acoplamiento bibliográfica.

Originalidad: Dada la importancia económica, social y tecnológica de la innovación, las políticas públicas aparecen como motores del desarrollo de la innovación, reforzando así la necesidad de identificar caminos inexplorados a través del mapeo de estudios sobre el tema para identificar caminos inexplorados.

Resultados: Identificamos las bases sobre las cuales se desarrolló el tema estudiado. Así, se observaron tres factores: Desarrollo Económico, Ecosistemas de Innovación y Participación del Estado. En el análisis de acoplamiento, identificamos cuatro factores, a saber: Emprendimiento, Cambios en las Políticas Públicas, Redes y Clusters y Fuente de Conocimiento. De cara al futuro, se presentaron algunas tendencias de estudio, destacando una nueva agenda de investigación.

Aportes teórico-metodológicos: Se presentaron algunas tendencias de estudio sobre innovación y políticas públicas, lo que amerita una nueva agenda de investigación.

Contribuciones a la gestión: Esta investigación permite a los gestores y tomadores de decisiones comprender los aspectos que envuelven el tema, para que puedan desarrollar acciones estratégicas de innovación con el apoyo de las políticas públicas.

Palabras-chave: Innovación. Políticas públicas. Entorno de innovación. Gestión de la innovación. Bibliometría.

\section{Introduction}

In a rapidly changing economic context, countries that manage to implement effective policies to stimulate innovation, can boost companies to become increasingly competitive 
(Figueiredo, 2016), as innovation is a valuable instrument for economic development (Willoughby, 2020). Companies and governments have directed efforts to boost investment in innovation to increase economic productivity (Emodi et al., 2017). There is a considerable set of circumstances that involve innovation as a dominant factor in terms of national and international economic growth. Even in liberal economies, in which the State has its minimum share, governmental actions occur through public policies, which aim to achieve certain objectives (Weisz, 2006).

Policies encouraging technological development and innovation have gained attention within policies aimed at improving the competitiveness of the productive system. This consideration assumed that innovation is crucial for economic growth (Fagerberg, 1994; Freeman, 1994; Lichtenberg \& Siegel, 1991). There are several mechanisms available for the development of innovation, and the most observed among them are technical mechanisms, mechanisms of technological diffusion, intellectual property system, instruments of market protection, and commercial promotion. Additionally, there are financial mechanisms, which are divided into financial incentives and tax incentives (Arora \& Cohen, 2015). Among the policies to support innovation, are incentives that occur directly, such as economic subsidy resources and subsidized loans, and incentives occurring indirectly, in the form of tax exemptions (Dini \& Stumpo, 2011).

The number of scientific studies on innovation has shown considerable growth (Fagerberg \& Verspagen, 2009; Martin, 2012). This rise surpasses the annual publications of the set of disciplines from other areas (Cancino et al., 2017), which allows us to understand that researchers from different fields of knowledge are interested in conducting research on innovation. The theme of innovation is emphasized in academic production and authors have performed studies aimed at seeking progress on the subject.

The knowledge matrix of innovation studies and public policies have sought to identify the main social and economic consequences (Fagerberg et al., 2012), such as, evaluation of public policies for innovation in renewable energy (Mendonça \& Fonseca, 2018); observation of public policies for the promotion of science parks and support for technology-based companies (Lecluyse et al., 2019); and understanding the characteristics of the Innovation System as an important facilitator of business networks and international connections (Lew et $a l ., 2018)$. Other authors have analyzed how a company's innovation performance is shaped by its political stakeholders and economically interested parties (Li et al., 2017), with emphasis on the importance of public policies and technological development to increase industrial 
production capacity and the country's economic expansion (Fagerberg, 1994; Freeman, 1994; Lichtenberg \& Siegel, 1991; Mazzucato, 2015).

Given the economic, social, and technological importance of innovation, public policies appear as drivers of the development of innovation, thus reinforcing the need for mapping studies on the subject to identify unexplored paths. The objective of this research is to perform a mapping of studies on innovation and public policies, presenting an overview of the scientific discussion on the subject to suggest proposals for future studies. Thus, the question that guides this research is: What are the determinants presented in scientific research involving innovation and public policies?

To answer this question, through statistical analysis we used bibliometric analysis techniques of citations, co-citations, and bibliographic coupling, making it possible to collect a large amount of bibliographic data, referring to articles that address the theme of this research, providing greater complexity in the analysis (Vogel \& Güttel, 2013; Zupic \& Cater, 2015). Studies with advanced bibliometric methods, like this one, delimit the frontiers of knowledge in a provided field, seeking to observe research structures, connection networks, researchers, and the themes that more frequently emerge from these works (Ramos-Rodríguez \& RuízNavarro, 2004; Vogel \& Güttel, 2013).

This work is structured into four sections, (1) introduction; (2) research method and technique; (3) results, discussions, and future challenges; (4) agenda for future research; and (5) conclusions.

\section{Research method and technique}

A bibliometric study aims to identify the path that the phenomenon takes to identify cohabitation and future studies (Prasad \& Tata, 2005; Serra, Ferreira, Guerrazzi, \& Scaciotta, 2018). In proposing this bibliometric analysis research in the field of study of Innovation and Public Policies, we agreed to exclusively consider scientific articles. This choice is common in theoretical studies, as this criterion presents greater methodological rigor with regard to the advancement of scientific knowledge. Thus, we conducted the study in four distinct stages.

In the first stage, we established the criteria on which the studies were listed, given the need for and importance of determining classification criteria and filters to specifically analyze the presented results (Cancino et al., 2017). The search covered the years from 2008 to 2017, in addition, we selected the Web of Science database. Web of Science allows the search for advanced structures through logical operators that meet the specifications, as well as filter tools 
for performing bibliometric analysis, providing valuable information for the type of study proposed in this research (Benavides et al., 2020). The choice of the database considered its prestige and international reputation (Fernández-Batanero, Montenegro-Rueda, FernándezCerero, \& García-Martínez, 2020) due to the peer-review process applied to all available publications, which reinforces the validity of knowledge (Podsakoff et al., 2005), as well as the high scientific rigor in the indexing of studies and the high number of publications, which enables a more comprehensive search (Fernández-Batanero et al., 2020).

In the second stage, we performed the analysis of the citations to present a view of the activity indicators, that is, the impact force or the influence of the research of a job. We noted the number of times that an article is cited by other researchers in their research. It is assumed in this study, that researchers seek to cite articles of greater relevance to their own research, which leads to consider that the most cited authors observed in this analysis of citations, tend to have greater influence on the topic (Culnan et al., 1990).

In the third stage, we identified the conceptual structure, that is, the co-citation analysis, to measure the frequency of joint citations of the same article in the same sample. In the analysis of the co-citation, we observed the relationship indicators in the volume of references to a given research, following the number of links and interactions between different researchers and different research fields (Ramos-Rodríguez \& Ruiz-Navarro, 2004). What this technique seeks is to measure the frequency with which a pair of articles is cited in the same sample (Mccain, 1990) and how this citation can lead to a representation of the conceptual foundations of a field (Zupic \& Cater, 2015), the description of the content, and the evolution of the research on the proposed theme (Serra et al., 2018).

In the fourth stage, we identified new research opportunities, through bibliographic coupling, showing the frequency in which two works are cited by the same reference. In the bibliographic coupling technique, the bibliographic reference overlay is presented, whose objective is to measure the frequency in which two works from the same sample end up citing in common in at least one reference (Kessler, 1963; Zupic \& Cater, 2015) and the representation of research trends of this analyzed sample (Vogel \& Güttel, 2013).

\subsection{Data collection and sample}

The authors used the terms "public policy" and innovat* as the first filter. With the mentioned terms, the search presented 1824 results, which when filtered by document type "article" resulted in 1403 articles. There were many fields of knowledge that would not be 
within the content to be researched, requiring further refinement, this time by category. The categories Management, Economics, Business, Planning Development, and Public Administration were chosen, thus obtaining 711 results. A time cut considered the years from 2008 to 2017, in view of the growing number of publications in this period, which resulted in 468 articles for analysis. Abstracts, cited references, times cited, authors, institutions and countries resulted in the data of interest to the research.

The relevance of publications regarded the journals in which the articles were published. In this sense, the journals were evaluated, considering the number of publications, and their impact factor over five years. The 468 articles published in the period are distributed in 184 journals. Table 1 presents the ten journals with the greatest representation of publications in the area.

\section{Table 1}

Journals and most relevant samples

\begin{tabular}{l|c|c|c}
\multicolumn{1}{c|}{ Journal $^{\mathbf{a}}$} & Index H $^{\mathbf{b}}$ & Impact factor $^{\mathbf{c}}$ & Sample $^{\mathbf{d}}$ \\
\hline Technological Forecasting and Social Change & 93 & 3,226 & 25 \\
\hline Research Policy & 206 & 6,265 & 18 \\
\hline European Planning Studies & 69 & 1,745 & 16 \\
\hline Science and Public Policy & 55 & 1,890 & 16 \\
\hline Journal of Technology Transfer & 66 & 2,777 & 14 \\
\hline Small Business Economics & 108 & 3,414 & 11 \\
\hline Energy Policy & 178 & 5,038 & 9 \\
\hline Technovation & 111 & 4,822 & 8 \\
\hline Review of Policy Research & 40 & 1,864 & 337 \\
\hline Other 175 journals & - & - & $\mathbf{4 6 8}$ \\
\hline Total & - & - & \\
\hline
\end{tabular}

Note: (a) mean journals; (b) Index H of the journal; (c) Impact factor of the journal; (d) articles per journal. Source: The authors based on the research data.

In this sample, Bradford's Law is easily explained, since few journals concentrate most of the relevant published articles in the research field. Of the journals used in this work, nine of them stand out in the evolution of the number of articles published over the years used as a reference for this research. Most notably, Technological Forecasting and Social Change alone represents $5 \%$ of total publications. Of the total sample of 468 articles used in this research, 131 of them originated from these nine journals, or $28 \%$ of the final sample. 


\subsection{Analysis procedures}

As suggested by Serra et al. (2018), we used the software Bibexcel to extract and organize data in an Excel spreadsheet. This process allowed us to observe the various objects of bibliometric study, such as authors, keywords, references, year of publication, journal, among others. We revised the primary information to ensure uniformity of references, correcting inconsistencies such as duplications, discrepancies in the writing of authors' names, journals, edition and year of publication. The Bibexcel software identified the most representative works of the sample selected based on periodicals used to compose this work. Bibexcel was responsible for generating the citation matrices, and the co-occurrence matrices: co-citation and coupling (Serra et al., 2018).

Co-occurrence matrices as adjacency matrices for network analysis is widely used as a tool in bibliometric works such as by Ramos-Rodríguez and Ruíz-Navarro (2004), and Lin and Cheng (2010). The authors used Ucinet, which is a software that provides different tools for developing statistics and demonstrations integrated into its platform. Thus, we analyzed the main factors of the co-citation matrix and bibliographic coupling using IBM SPSS. For cocitation matrices and bibliographic coupling, we conducted an Exploratory Factor Analysis (EFA) with Varimax rotation (Acedo et al., 2006; Lin \& Cheng, 2010; Serra et al., 2018).

\section{Results, discussions and future challenges}

This section consists of citation analysis, co-citation analysis, and bibliographic coupling analysis and presents the results, discussion, and future challenges for the theme Innovation and Public Policies.

\subsection{Publication and citation analysis}

There is a fluctuation in the number of articles published on the themes from 2008 to 2017. Most of the publications on innovation and public policies took place in 2013, 2015, 2016 and 2017. Although there is an intermittence in the total number of publications, the number of citations has increased. As of 2015 these numbers jump to a total of 910 citations, which means $71.31 \%$ more citations than in 2014. These numbers continued to rise with a growth of $72.63 \%$ in 2016 and a total of 1,253 citations throughout the year. In 2017, the number increased to a total of 1,618 citations (Figure 1). 


\section{Figure 1}

Publications X Citations (2008-2017)

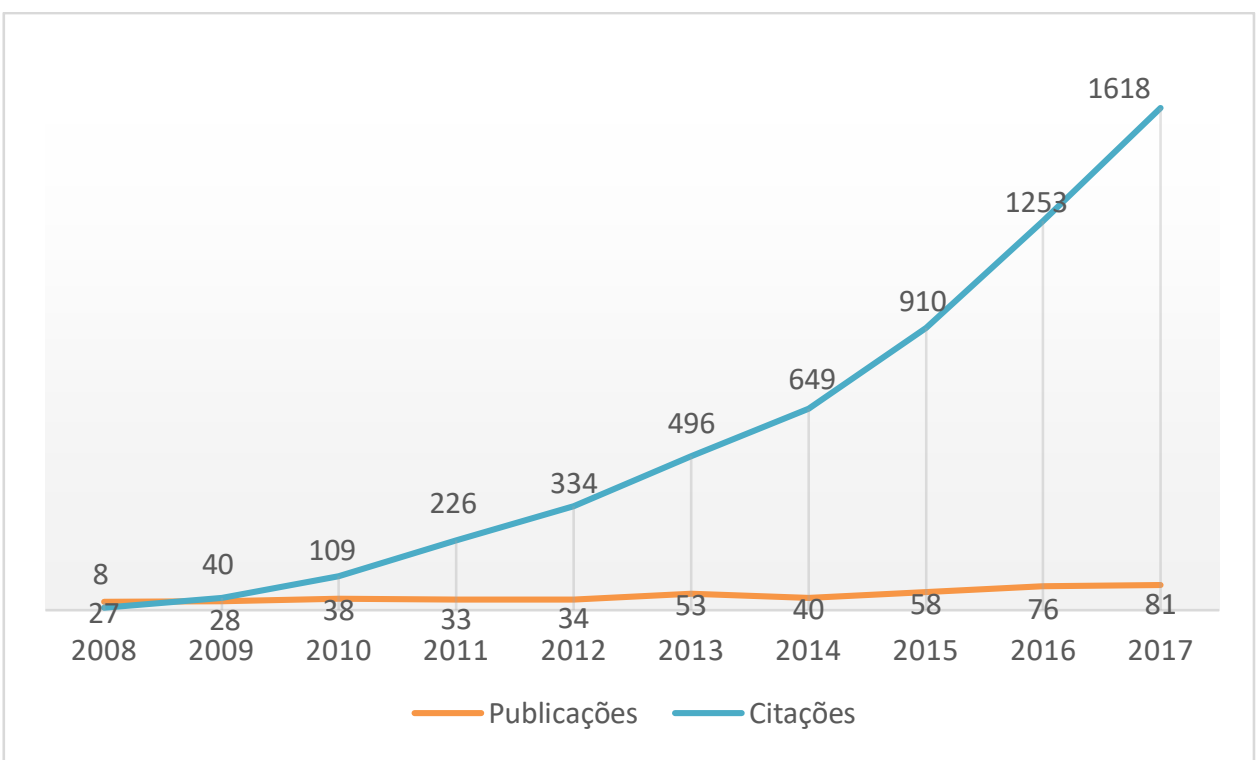

Source: Own elaboration based on data from Web of Science.

Given the data presented, it is possible to identify an increase when observing the citations, different from the number of publications that appear with a discontinued production. Even so, there are numbers that cannot be ruled out, evident by the total of 468 articles published in the analyzed period with the highest concentration of publication in 2017. Quantifying citations were a total of 5,643 in the last decade, growing significantly over the years.

In view of the analysis, it was possible to identify 983 authors in scientific production over ten years. Ross Brown appears with the largest number of publications (6), followed by Colin Mason (5), and later Franco Malerba (4). Observing these data, a variety of authors can be seen discussing the theme that involves Innovation and Public Policies.

In view of the data, it is possible to observe a variety of authors discussing the topic of interest of this bibliometric study. Ross Brown appears with the greatest number of publications. In one article published in 2017, Ross Brown reviews the literature evaluating the ambiguities of definition in the concept of entrepreneurial ecosystems. The article indicates some perceptions about differentiated technology companies discovering, creating, and promoting innovation opportunities with the implications regarding public policies. The author published another article in 2017 and considered the offer of bank financing for innovative small and medium-sized companies in the United Kingdom. The article finds evidence of increased demand for bank financing for innovative companies in peripheral areas. However, these companies are more likely to be discouraged from applying and there is strong evidence 
that innovative companies in peripheral regions are more likely to reject financing requests, even when controlling for factors such as credit scores. The findings suggest that geography is important in financing innovative companies. Moreover, the same happens to companies in peripheral areas that may experience a "distance liability" that potentially reinforces regional disparities. The policy implications of these findings are outlined.

In 2016, Ross Brown had two more articles published. One points to the failure of public policy aimed at regional innovation in Scotland, called the Intermediate Technology Initiative. The article shows that the initiative was an ambitious instruments of systemic regional innovation policy developed in the United Kingdom in recent years. However, few of the expected results were achieved and the program was prematurely ended. The article examines the reasons for its failure, largely focusing on inappropriate program design. The survey results suggested that greater recognition should be given to the specificities of local entrepreneurial ecosystems when designing, aligning, and executing systemic innovations and public policy instruments. The conclusions pointed that paying more attention to public policy failures could help innovation scholars better understand how innovation systems work.

The other publication by Brown disagrees with the emphasis placed on universities as one of the responsible for the growth of local economies, receiving a central role in regional innovation systems. The author claims that universities make their contribution, but also claims that "political entrepreneurs" play a powerful role in the cumulative reinforcement of the dominant role of universities through a process of "institutional capture", which results in a form of "politics of imprisonment".

In the article published in 2014, Brown highlights the incongruity between the nature of companies and the public sector technology policies designed to support them. Qualitative data reveals that these companies are typically corporate rather than university derived and that most do not carry out significant internal Research \& Development. Most companies also derive their main competitive advantages from open innovation. The paper offers suggestions on tailoring policy to better reflect the requirements of local entrepreneurial and the types of support required by most high-tech small and medium enterprises.

Regarding the most cited articles, Renewable Energy Policies and Technological Innovation: Evidence Based on Patent Counts, published in 2010 by Johnstone, Nick, Hascic, Ivan, Popp, and David, in the journal Environmental \& Resource Economics, is ranked first in a list with a total of 375 citations. In that article, the authors study the effect of environmental policies on technological innovation specifically on the case of renewable energies and perform 
an analysis using patent data in a panel of 25 countries over the period from 1978 to 2003 . The authors conclude that public policy plays a significant role in determining patent applications.

In second place, with 306 citations, is the article Why Encouraging More People to Become Entrepreneurs is Bad Public Policy, published in Small Business Economics in 2009 by Scott Shane. The article presents critically public policies aimed at innovation that focus on creating more companies in order to transform undeveloped economic regions. The author points out that this belief is flawed because startups are not always innovative, and that these actions create few jobs and generate little wealth. Shane also defends that public policies should encourage the formation of high-quality, high-growth companies and concludes that, although government officials are not able to "pick the winners", they can identify startup companies as a low probability of generating jobs. By removing incentives to create these low-probability companies, policymakers may improve the average performance of new businesses and thus promote economic development.

The third most cited article, with 221 citations and published in 2010, is An evolutionary Approach to Understanding International Business Activity: The Co-evolution of MNEs and the Institutional Environment, in the Journal of International Business Studies. The article presents the development of a theoretical framework relating the historical changes in the activities of multinational companies regarding the institutional environment, with emphasis on the co-evolution of technology and institutions. The conclusions indicated that the form of coevolutionary analysis has become increasingly important to understand the interrelationships between the activities of multinational companies and public policy.

\subsection{Co-citation Analysis}

The co-citation analysis identified the main foundations of each of the detected factors to highlight the main characteristics of the works that compose the factors of this co-citation and to explore its points and counterpoints in the analyzed factors. We performed an Exploratory factor analysis in the bibliometric analysis, agglutinating the sample into factors considering the relationships among references; thus, the cross-loadings represent a paper belonging to more than one factor. However, we performed the analysis according to the procedures recommended by Hair et al. (2014) who evaluated the KMO> 0.5 of each item in the anti-image matrix, the general KMO> $0.5(.808)$ with the exclusion of items with commonality $<0.5$. Items with loads $>0.5$ in one factor and items with loads named by the authors as "crossed" $>0.5$ in more than one factor were also excluded. In the end, we evaluated 
each factor with an internal reliability (Cronbach's alpha) whose value was $>0.6$. At the end of the extractions, the authors identified three factors that correspond to $65.05 \%$ of the total explained variance, as shown in Table 2.

The factors were named based on the reading and analysis of the articles that form the components and their factor loads: Factor 1 "Economic Development", Factor 2 "Innovation Ecosystems" and Factor 3 "State Participation".

\section{Table 2}

Component matrix of components - co-citation

\begin{tabular}{l|c|c|c}
\hline \multirow{2}{*}{} & \multicolumn{2}{|c}{ Component } \\
\cline { 2 - 4 } & $\begin{array}{c}\text { Economic } \\
\text { Development }\end{array}$ & $\begin{array}{c}\text { Innovation eco- } \\
\text { systems }\end{array}$ & $\begin{array}{c}\text { State } \\
\text { participation }\end{array}$ \\
\hline Romer (1986) & .814 & & \\
\hline Solow (1956) & .790 & & \\
\hline Arrow (1962) & .750 & & \\
\hline Lucas (1988) & .723 & .824 & \\
\hline Romer (1990) & .700 & .812 & \\
\hline Malerba (2002) & & .782 & \\
\hline Lundvall (2007) & & .742 & \\
\hline Freeman (1987) & & .607 & \\
\hline Cooke et al. (1997) & & & \\
\hline Freeman (1995) & & & \\
\hline Walker (1969) & & & \\
\hline Kingdon (1984) & & & \\
\hline Not Extan & & & \\
\hline
\end{tabular}

Note: Extraction Method: Principal Component Analysis. Rotation Method: Varimax with Kaiser Normalization. The Converged rotation in 4 iterations.

Source: The authors, based on research data.

Factor 1 - Economic Development: The articles that comprise the first factor in the coquotation matrix deal with Economic Development linked to Innovation. Technological changes favor economic growth, particularly when observed in the long term (Romer, 1986). The economic system develops when growth occurs in a balanced manner and its main 
developer is the capital-product relationship (Solow, 1956). Economic development needs to consider a model that has the accumulation of physical capital and technological change (Lucas, 1988). Economic growth is a variable dependent on the 'Knowledge' variable, which is difficult to measure. From a quantitative and empirical point of view, it establishes 'Time' as an explanatory variable. It presents a harsh criticism of the projections of trends that are presented in a necessary way, but it can only be a practical point of view without considering political variables. Economic Development is driven by technological change that arises from intentional investment decisions made by agents that aim to maximize profit. Integration into world markets will increase growth rates, but having a large population is not enough to generate growth (Romer, 1990).

Factor 2 - Innovation Ecosystem: The concept of Innovation Ecosystem appears in the second factor, providing a multidimensional, integrated, and dynamic vision of the sectors, which favors the interaction of agents interested in innovation (Malerba, 2002), thus demonstrating its importance both in a theoretical scenario and in a political scenario (Lundvall, 2007). The Innovation System is recognized for its important contribution (Cooke et al., 1997), however due to conceptual and methodological issues, primarily in relation to problems of scale and complexity, this approach could be complemented considerably, if the perspective of the formulation of a regional Innovation System was directed. National and regional innovation systems are essential to perform economic analysis. The creation of the Innovation System derives from the importance of relationship networks, which are necessary for any company to innovate. The influence of the innovation system is fundamental, in view of its interrelationship with industries, technical and scientific institutions, government policies, and cultural traditions (Freeman, 1995).

Factor 3 - State Participation: The third factor presents articles aimed at State participation and highlights studies that were conducted on social, political, and economic bases. The studies illustrate that the relative wealth of a State, its degree of industrialization, and other measures of social and economic development are important to explain its level of spending. Factors such as the level of personal income and the size of the urban population are responsible for the degree of a state's participation and competition. Public policy spending levels and actual service levels are rarely correlated. Some states are able to achieve certain levels of services at less expense than others. Therefore, it is necessary to establish an adequate level of expenditure for a public policy program, as well as the scope related to the program (Walker, 1969). To better understand the formulation of public policies (Kingdon, 1984) the 
realization of an empirical research is necessary since previous studies sought understanding through government agendas.

\subsection{Bibliographic coupling analysis}

In Table 3, we grouped the bibliographic coupling factors. The articles were grouped into four factors that measure the use of the same reference by two or more articles, making it possible to understand the trend of the theme, around what was published. As in the co-citation analysis, we conducted an Exploratory Factor Analysis, correlating items to factors. The authors performed the analysis according to the procedures recommended by Hair et al. (2014) who evaluated the KMO> 0.5 of each item in the anti-image matrix, the general KMO> $0.5(.806)$ excluding items with 0.5 factor commonality, and items with loads denominated by the authors as "crossed" $>0.5$ in more than one factor were also excluded. The internal reliability of each factor (Cronbach's alpha) whose value was $>0.6$ was evaluated. At the end of the extractions, four factors were identified, corresponding to $63.47 \%$ of the total explained variance.

Table 3

Component matrix - coupling

\begin{tabular}{l|c|c|c|c}
\hline \multirow{2}{*}{} & \multicolumn{3}{|c}{ Component } \\
\cline { 2 - 5 } & Entrepreneurship & $\begin{array}{c}\text { Changes in } \\
\text { public } \\
\text { policies }\end{array}$ & $\begin{array}{c}\text { Nets and } \\
\text { Clusters }\end{array}$ & $\begin{array}{c}\text { Knowledge } \\
\text { source }\end{array}$ \\
\hline Minniti (2008) & .877 & & & \\
\hline Komlósi et al. (2015) & .853 & & & \\
\hline Acs and Amorós (2008) & .790 & & & \\
\hline Pathak et al. (2013) & .715 & & & \\
\hline Schubert (2015) & .712 & & & \\
\hline Thurik et al. (2013) & .709 & & & \\
\hline Mas-Tur and Soriano (2014) & .699 & & & \\
\hline Mintrom (2013) & & .902 & & \\
\hline Uyarra and Flanagan (2010) & & .860 & & \\
\hline Holyoke et al. (2009) & & .811 & & \\
\hline Boushey (2012) & & .794 & & \\
\hline Heikkila et al. (2014) & & & .794 & \\
\hline Visser and Atzema (2008) & & & & \\
\hline Wonglimpiyarat (2017) & & & & \\
\hline Laranja et al. (2008) & & & & \\
\hline Schmitz and Altenburg (2015) & & & & \\
\hline
\end{tabular}




\begin{tabular}{l|c|c|c|c}
\hline \multirow{2}{*}{} & \multicolumn{3}{|c}{ Component } \\
\cline { 2 - 4 } & Entrepreneurship & $\begin{array}{c}\text { Changes in } \\
\text { public } \\
\text { policies }\end{array}$ & $\begin{array}{c}\text { Nets and } \\
\text { Clusters }\end{array}$ & $\begin{array}{c}\text { Knowledge } \\
\text { source }\end{array}$ \\
\hline Kasabov and Delbridge (2008) & & & .700 & \\
\hline Gomez and Vargas (2009) & & & & .855 \\
\hline Amponsah and Adams (2017) & & & & .762 \\
\hline Sherwood and Covin (2008) & & & & .734 \\
\hline Moilanen et al. (2014) & & & & .657 \\
\hline
\end{tabular}

Note: Extraction Method: Principal Component Analysis. Rotation Method: Varimax with Kaiser Normalization. The Converged rotation in 5 iterations.

Source: The authors, based on research data.

As in the co-citation analysis, the factors were named based on the reading and analysis of the articles that form the components and their factor loads: Factor 1 "Entrepreneurship", Factor 2 "Changes in Public Policies", Factor 3 "Networks and Clusters and Factor 4 "Source of Knowledge". Next, we advance to an exploration of the main topics and main findings of each theme. It is nearly impossible to summarize while doing research justice in numerous and diverse articles in such a wide area, but a few observations on each topic can at least provide a useful overview. We focused on the discoveries that appeared most important to advance the field and bring the elements together.

Factor 1 - Entrepreneurship: The first factor presents articles that address entrepreneurship that favors innovation. In turn, public policy appears responsible for shaping the institutional environment, in which entrepreneurial decisions are made. Thus, public policies are essential for the development of entrepreneurship (Minniti, 2008). Entrepreneurship has been presented as the main driver of economic development, growth, competitiveness, employment, productivity, and innovation (Komlósi et al., 2015). Public policies are essential to strengthen the creation of effective innovative businesses. Entrepreneurship is considered an important mechanism for economic development, in view of its effects on job creation, product and service offerings, and well-being (Acs \& Amoros, 2008).

Systems with strong protection of intellectual property rights, combined with high levels of foreign investment, decrease the likelihood of individuals entering technology entrepreneurship, while low barriers to technological adoption increase this likelihood. These discoveries contributed to the understanding of the influence that national institutions and foreign investment have on the entrepreneurial behavior of technology businesses at an early stage in emerging economies (Pathak et al., 2013).

Following is an investigation on the innovation and entrepreneurship policy, observing which are the most effective political measures in the promotion of productive business 
activities, highlighting the neglect directed at the positive (political economy) and normative (well-being) dimensions (Schubert, 2015). Technological change is an essential catalyst, underlying the change in the economy managed by corporate businesses. However, not only technological change, but a multiplicity of factors, ranging from the advance of globalization, corporate reorganization, and increased knowledge production are of paramount importance for business economic development (Thurik et al., 2013).

There is a relationship between difficulties in obtaining financing and the ability to manage new companies (Mas-Tur \& Soriano, 2014). Thus, it is important that requests for public subsidies for the development of innovation by new companies must be accompanied by technical assistance and advisory services.

Factor 2 - Changes in Public Policies: The co-citation analysis points out that the coupling analysis also demonstrated public policies in their component, but in a different context. The studies that emerged in this factor show that public policies need to be transformed, and that the evolutionary process and its driving forces must be in focus, and not just its results. Controversies between scientific communities, governments, and religious entities have punctuated the history of Western civilization. These controversies focused on issues of knowledge, power, and control. The scrutiny of public debates and policy choices in relation to science offers insights into contemporary politics, policy making, and the design of effective governance systems. Political entrepreneurs are political actors who seek policy changes that have altered the status quo in certain areas of public policy (Mintrom, 2013). Public contracts appeared as a public policy for change, and today they represent a significant proportion of the general demand for goods and services and are increasingly seen as an attractive and viable tool to promote the objectives of innovation policy (Uyarra \& Flanagan, 2010).

Demands on changes in the State and the learning of successes and failures of neighboring nations play significant roles in the dynamics of public policies. Some public policies move slowly through the legislative process and are subject to re-conceptualization, refinement, and commitment as they gradually acquire and maintain winning coalitions. Others, however, enter the decision-making agenda and are quickly enacted. This may simply be legislators imitating what other states do, or it may result from political administrators and entrepreneurs traveling in professional networks where they exchange new ideas, disclosing the best. If states are quicker to import policy models from their neighbors, as the literature suggests, this need not be simply because lawmakers are more likely to hear about innovations beyond their borders (Holyoke et al., 2009). 
Legislators, feeling that the cultural, social, and political context can affect the success of policies, can reasonably infer that the programs that seem to work when applied by neighbors are more likely to be successfully transferred than policy projects that originate in more distant places. Either way, the perceived successes or failures of neighboring states can also cause a state's legislation to change in a more permissive or restrictive direction. In short, while reversal and imprisonment see policy driving change, the learning model holds that, over time, these factors become less influential than the needs of the state and the return of a policy's success (Holyoke et al., 2009).

Balance theory provides a unifying framework for underestimating three mechanisms that lead to the spread of innovations: gradual policy diffusion driven by the emulation of incremental policies, rapid diffusion from state to state driven by policy imitation, and almost immediate policy diffusion drove by state-level responses to a common exogenous shock (Boushey, 2012). Although most policies spread gradually, consistent with incremental policy learning and emulation, a significant subset of innovation triggers policy spreads as states across the country mimic a new popular initiative. In this sense, the policy diffusion process produces patterns of policy change consistent with cycles of positive and negative returns (Boushey, 2012).

The diffusion processes work on the assumption that the units, from people to governments, are interdependent. What diffusion models of policy change suggest is that policy change may be more likely when actors learn or observe policy ideas adopted or implemented by other governments or decision-making units. Therefore, the adoption of similar policies from other governmental jurisdictions will precipitate policy change (Heikkila et al., 2014).

Factor 3 - Networks and Clusters: The creation of clusters through public policies is risky, complex, and costly. In addition, it advances knowledge by claiming that it is not necessary to have clusters to stimulate innovation. A network approach combined with the intention of improving innovation and stimulating economic growth is seen as efficient and effective. For the creation of a network, it is necessary to consider regional knowledge in terms of sectors, life cycles, and institutional and socio-cultural factors. The role of public policies is to assist in recruiting, providing initial funding, and monitoring available resources. With this, the policy moves towards a decentralized innovation system, based on processes, specific to each region, spatially divergent and multilevel, focused on the innovation and evolution strategies of companies (Visser \& Atzema, 2008). 
High-tech companies are important for improving innovative capacity. Many countries use taxes as one of the public policy instruments to provide an enabling environment for the growth of high-tech companies. Fiscal policies and research and development (R\&D) incentives have a strong relationship with the development of science and technology. In contrast to the study by Visser and Atzema (2008), cluster policies are mentioned as a mechanism that improves the effectiveness of the National Innovation System. For Wonglimpiyarat (2017), clusters are recognized as an important political instrument to facilitate innovation and support transdisciplinary research networks between academics and entrepreneurs, which would improve the capacity of nations.

While economic theories provide principles for justifying public intervention and general policy guidelines, they are not always prescriptive in terms of choosing policy instruments. Concepts and theories that underline the justifications for regional Science, Technology, and Innovation policies should be taken as heuristic tools that provide guidance for policy design, especially with regard to policy goals, motivations, and targets (Laranja et al., 2008).

The view of regional innovation systems has been criticized for implying regions can be considered complete and closed systems. However, the scope of regional political jurisdiction may not coincide with the geographic socio-economic space in which the relevant interactions of "institutions" and "interactive learning" are to be promoted. In addition, at smaller spatial scales, system dysfunctions and entrapment situations may require access to knowledge outside the regional system. Thus, many of the relevant public companies and institutions, as well as the main relationships can be extra and regional policies, presumably they would also need to promote and support external links with other "innovation systems" at different territorial levels (Laranja et al., 2008).

There are important implications if a diversity of paths appears or a small number of projects become globally dominant. First, for the natural environment, continuous diversity would help to mobilize a wide range of talents and resources and would lead to more contextspecific solutions. Conversely, convergence is more likely to provide economies of scale, allowing for a rapid reduction in costs, which allows new technologies to emerge and replace unsustainable technologies. Second, it matters for competition and the distribution of earnings in the global economy. Sustained diversity can provide niches for companies, while a globally dominant design is likely to favor concentration on global companies and value chains. In the latter case, it makes a considerable difference whether the holders of the former industrialized 
countries maintain or even reinforce their global position or whether they will be overtaken by the newcomers, especially if they come from newly industrialized economies. Governments can influence innovation through explicit or implicit policies and can intervene in the innovation cycle. They can use a wide range of instruments to encourage or discourage economic activities, including taxes, subsidies, regulations, and all types of coordination and facilitation services (Schmitz \& Altenburg, 2015).

There is growing political assistance to innovation from clusters, regions, and networks of importance and a strong incentive to regional / national competitiveness. The measures of innovation inputs and outputs are due to the creation, sharing, learning, and knowledge in research on clusters, communities, regions, and national systems. It is important to underline that there is a need to invest in a differentiated view of each region so that an approach to public policies is done in a manner appropriate to the unique needs (Kasabov \& Delbridge, 2008), these being some of the political challenges.

Factor 4 - Knowledge Source: An investigation about the factors that affect the adoption of new technologies. Thus, the study offers special attention to the effect of financial resources and the absorption capacity in the decision to adopt new technologies at the company level (diffusion between companies). It is argued in favor of a negative effect of financial restrictions providing reasons for a differential effect of internal and external R\&D in adopting innovation. In addition, complementarities arise when companies adopt several new technologies. Financial restrictions depend on the technology analyzed, while only internal investments in R\&D are strong predictors of adoption (Gomez \& Vargas, 2009).

The generation of internal product and process innovations are based on a company's technological knowledge. However, such technological knowledge is not only accumulated through internal learning processes. To acquire the technological knowledge necessary to introduce innovations, companies have resorted to external sources (Sherwood \& Covin, 2008).

Traditionally, companies depend on internal knowledge to develop and nurture ideas within the company until they are launched as new products or businesses. Companies can and should use internal and external ideas and paths to the market, as they seek to improve their technology. There is a general demand for companies to adopt this new way of thinking, to explore trends such as the growing availability and mobility of skilled workers, the growth of venture capital, and the increasing quality of suppliers, along with trends that erode advantages of closed innovation (Amponsah \& Adams, 2017). 
The relationship between external knowledge and innovation suggests that the benefit of external knowledge flows cannot be taken for granted. In particular, it is crucial that the company is able to identify and assess the potential value of relevant external knowledge. The results are consistent with the absorption capacity as an important mediator to transform external knowledge inputs into innovative performance (Moilanen et al., 2014).

Figure 2 presents the coupling analysis map on innovation and public policies.

\section{Figure 2}

Coupling Net

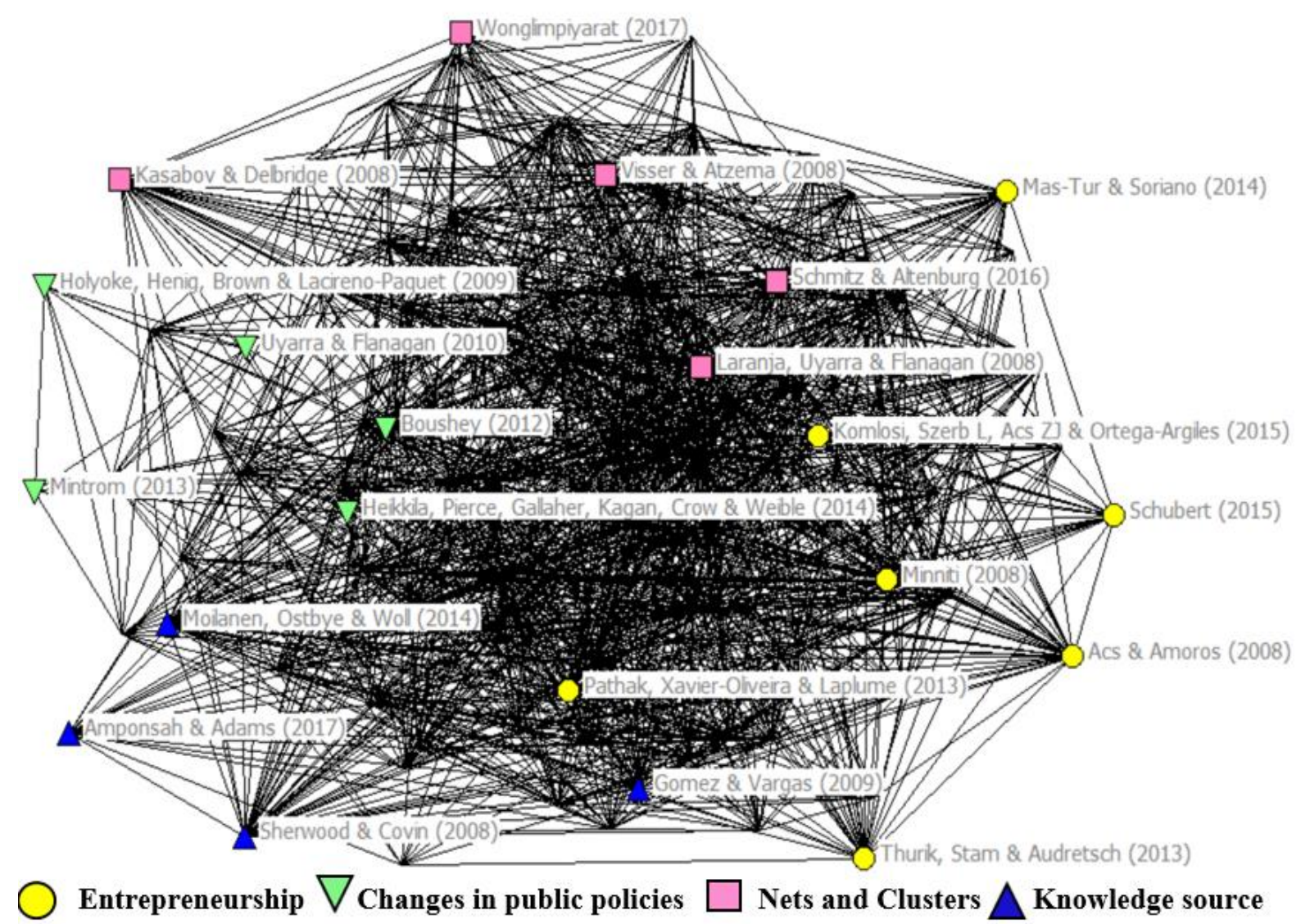

Source: The authors.

\section{Agenda for future research}

As noted, many of the concepts and theoretical connections presented have been consistently studied. However, some concepts are less precisely defined, and some theoretical links are not presented. These deficiencies present research opportunities. 
First, related to the Entrepreneurship factor, studies that investigated to determine which characteristics constitute the effectiveness of public policies seem promising. In the case of innovation policies, it would be interesting to see if there is a positive relationship between the effectiveness of using public policies and startups, and incubation / acceleration programs as a moderating factor. Another possibility would be to check if governments consider startups as a target in their public innovation policies.

Another important issue would be to analyze whether public policy makers consider effective innovative businesses, since they play a fundamental role in transforming industries. Variables such as use of subsidies, region, infrastructure, and knowledge transfer can be considered in this type of analysis.

Still, the entrepreneurial activity can be studied as a mechanism of transformation and economic growth, which is an interesting phenomenon that poses a great challenge for future research. Entrepreneurship and innovation, particularly in high technology, are issues increasingly related to clusters and networks. They are composed of many component organizations, private, public, nonprofit, and others that are interrelated in complex ways. Understanding the role of public policies in this configuration requires viewing the system as a whole, and not the individual component parts, which is one of the main challenges for policy makers and academics.

A second area of research is related to changes in public policies. A research agenda that looks at all contexts and types of public procurement, as well as their impacts on innovation, can be valid and is recommended. Another possible contribution to the advancement of research would be the observation of cases of political entrepreneurship in the search for government funding and favorable regulation. Analyzing the effect of public innovation policies and the development of institutions, in response to changes in economic conditions, incentives, and pressures would also be a challenge.

The study of policy diffusion has sometimes ignored the problem-definition process that leads to policy change, so identifying how state attributes or the complexity of innovation relate to patterns of diffusion would a direction to search.

Third, networks and clusters have drawn substantial attention from policymakers, as they provide a framework for producing economic transformation. In the academic environment, it has not been different, the information on clusters has been debated, and the understandings regarding its facilitation to the development of innovation have been diversified. Therefore, a study that presents the cluster structure, the development of innovation, 
and that addresses the main functions of innovation systems is proposed. Still, it is argued that paying more attention to the failures in public policies could help innovation scholars to better understand how innovation ecosystems, networks, and clusters work, and this is another approach for future research.

Finally, examining source of knowledge, an integrated structure that helps managers to decide when and how to implement open innovation practices, seems to be a research opportunity. Managers need to decide at what stage of the innovation process is collaboration most effective and with which parties to collaborate It would be important to identify whether the accumulation of external knowledge has a positive effect on the systematization of innovation in organizations.

\section{Conclusions}

The main objective of this research was to perform a mapping of studies on innovation and public policies, presenting an overview of the scientific discussion on the subject to suggest proposals for future studies.

The Innovation Ecosystems are present in the studies that built its conceptual base and still point out indicators to be studied. Product and process innovation are the most mentioned constructs, as well as the acquisition of new technologies. However, R\&D has been observed with enthusiasm, as it is understood that profit making also occurs through the design of inventions and patents.

As a theoretical implication, in this article, we present some study trends on innovation and public policies, warranting a new research agenda. As a practical contribution, this research allows managers and decision makers to understand the aspects of the themes, so that they can develop strategic innovation actions with the support of public policies.

Although we propose a future research agenda, there are two limitations that should be noticed in new studies. The first limitation is the delimitation of the search for articles in only one database. Although the database used is reliable and reputable, expanding searches in other databases can provide opportunities for the analysis of a larger number of cases and, consequently, could bring greater diversity on the subjects innovation and public policies. The second limitation is related to the string of keywords used in the searches. There is a diversity of the terms that can be used and that represent public policies in the field of innovation. It should be noted that our intention was not to carry out an exhaustive review on the themes, but a representative one and, therefore, these two limitations were expected. 


\section{References}

Acedo, F. J., Barroso, C., \& Galan, J. L. (2006). The resource-based theory: dissemination and main trends. Strategic management journal, 27(7), 621-636. https://doi.org/10.1002/smj.532

Acs, Z. J., \& Amorós, J. E. (2008). Introducción: El proceso de creación de empresas. Estudios de economía, 35(2), 121-132. http://dx.doi.org/10.4067/S071852862008000200001

Amponsah, C. T., \& Adams, S. (2017). Open innovation: Systematisation of knowledge exploration and exploitation for commercialisation. International Journal of Innovation Management, 21(03), 1750027. https://doi.org/10.1142/S136391961750027X

Arora, A., \& Cohen, W. M. (2015). Public support for technical advance: the role of firm size. Industrial and Corporate Change, 24(4), 791-802. https://doi.org/10.1093/icc/dtv028

Arrow, K. J. (1962). The economic learning implications of by doing. The Review of Economic Studies, 29(3), 155-173. https://doi.org/10.2307/2295952

Benavides, L. M. C., Tamayo Arias, J. A., Arango Serna, M. D., Branch Bedoya, J. W., \& Burgos, D. (2020). Digital transformation in higher education institutions: A systematic literature review. Sensors, 20(11), 3291. https://doi.org/10.3390/s20113291

Boushey, G. (2012). Punctuated equilibrium theory and the diffusion of innovations. Policy Studies Journal, 4O(1), 127-146. https://doi.org/10.1111/j.1541-0072.2011.00437.x

Cancino, C. A., Merigó, J. M., \& Coronado, F. C. (2017). A bibliometric analysis of leading universities in innovation research. Journal of Innovation \& Knowledge, 2(3), 106124. http://dx.doi.org/10.1016/j.jik.2017.03.006

Cooke, P., Uranga, M. G., \& Etxebarria, G. (1997). Regional innovation systems: Institutional and organisational dimensions. Research policy, 26(4-5), 475-491. https://doi.org/10.1016/S0048-7333(97)00025-5

Culnan, M. J., O'Reilly III, C. A., \& Chatman, J. A. (1990). Intellectual structure of research in organizational behavior, 1972-1984: A cocitation analysis. Journal of the American Society for Information Science, 41(6), 453-458. https://doi.org/10.1590/19827849rac20142022

Dini, M., \& Stumpo, G. (2011). Políticas para la innovación en las pequeñas y medianas empresas en América Latina [Documentos de Proyectos, No 403]. Economic Comission for Latin America and the Caribbean, Cepal, 167.

Emodi, N. V., Murthy, G. P., Emodi, C. C., \& Emodi, A. S. A. (2017). Factors influencing innovation and industrial performance in Chinese manufacturing industry. International Journal of Innovation and Technology Management, 14(06), 1750040. https://doi.org/10.1142/S0219877017500407 
Fagerberg, J. (1994). Technology and international differences in growth rates. Journal of economic Literature, 32(3), 1147-1175.

Fagerberg, J., Fosaas, M., \& Sapprasert, K. (2012). Innovation: Exploring the knowledge base. Research policy, 41(7), 1132-1153. https://doi.org/10.1016/j.respol.2012.03.008

Fagerberg, J., \& Verspagen, B. (2009). Innovation studies-The emerging structure of a new scientific field. Research policy, 38(2), 218-233. https://doi.org/10.1016/j.respol.2008.12.006

Fernández-Batanero, J. M., Montenegro-Rueda, M., Fernández-Cerero, J., \& García-Martínez, I. (2020). Digital competences for teacher professional development. Systematic review. European Journal of Teacher Education, 1-19. https://doi.org/10.1080/02619768.2020.1827389

Figueiredo, P. N. (2016). Evolution of the short-fiber technological trajectory in Brazil's pulp and paper industry: The role of firm-level innovative capability-building and indigenous institutions. Forest Policy and Economics, 64, 1-14. https://doi.org/10.1016/j.forpol.2015.12.008

Freeman, C. (1987). Technology, policy, and economic performance: lessons from Japan. London: Pinter.

Freeman, C. (1994). The economics of technical change. Cambridge journal of economics, 18(5), 463-514.

Freeman, C. (1995). The 'National System of Innovation'in historical perspective. Cambridge Journal of economics, 19(1), 5-24. https://doi.org/10.1093/oxfordjournals.cje.a035309

Gomez, J., \& Vargas, P. (2009). The effect of financial constraints, absorptive capacity and complementarities on the adoption of multiple process technologies. Research Policy, 38(1), 106-119. https://doi:10.1016/j.respol.2008.10.013

Hair, J. F., Black, W. C., Babin, B. J., \& Anderson, R. E. (2014). Exploratory factor analysis. Multivariate data analysis, 7th Pearson new international ed. Harlow: Pearson.

Heikkila, T., Pierce, J. J., Gallaher, S., Kagan, J., Crow, D. A., \& Weible, C. M. (2014). Understanding a period of policy change: The case of hydraulic fracturing disclosure policy in Colorado. Review of Policy Research, 31(2), 65-87. https://doi:10.1111/ropr.12058

Holyoke, T. T., Henig, J. R., Brown, H., \& Lacireno-Paquet, N. (2009). Policy dynamics and the evolution of state charter school laws. Policy Sciences, 42(1), 33-55. https://doi:10.1007/s11077-009-9077-3

Kasabov, E., \& Delbridge, R. (2008). Innovation, embeddedness and policy: evidence from life sciences in three UK regions. Technology Analysis and Strategic Management, 20(2), 185-200. http://dx.doi.org/10.1080/09537320801931671 
Kessler, M. M. (1963). Bibliographic coupling between scientific papers. American documentation, 14(1), 10-25. https://doi.org/10.1002/asi.5090140103

Kingdon, J. W., \& Stano, E. (1984). Agendas, alternatives, and public policies, 45, 165-169. Boston: Little, Brown.

Komlósi, É., Szerb, L., Ács, Z. J., \& Ortega-Argilés, R. (2015). Quality-related regional differences in entrepreneurship based on the GEDI methodology: The case of Hungary. Acta Oeconomica, 65(3), 455-477. https://doi.org/10.1556 / 032.65.2015.3.6

Laranja, M., Uyarra, E., \& Flanagan, K. (2008). Policies for science, technology and innovation: Translating rationales into regional policies in a multi-level setting. Research policy, 37(5), 823-835. https://doi.org/10.1016/j.respol.2008.03.006

Lecluyse, L., Knockaert, M., \& Spithoven, A. (2019). The contribution of science parks: A literature review and future research agenda. The Journal of Technology Transfer, 44(2), 559-595. https://doi.org/10.1007/s10961-018-09712-X

Lew, Y. K., Khan, Z., \& Cozzio, S. (2018). Gravitating toward the quadruple helix: international connections for the enhancement of a regional innovation system in Northeast Italy. $R \& D$ Management, 48(1), 44-59. https://doi.org/10.1111/radm.12227

Li, J., Xia, J., \& Zajac, E. J. (2017). On the duality of political and economic stakeholder influence on firm innovation performance: Theory and evidence from Chinese firms. Strategic Management Journal, 39(1), 193-216. https://doi.org/10.1002/smj.2697

Lichtenberg, F. R., \& Siegel, D. (1991). The impact of R\&D investment on productivity-New evidence using linked R\&D-LRD data. Economic inquiry, 29(2), 203-229. https://doi.org/10.3386/w2901

Lin, T. Y., \& Cheng, Y. Y. (2010). Exploring the Knowledge Network of Strategic Alliance Research: A Co-citation Analysis. International Journal of Electronic Business Management, $8(2)$.

Lucas Jr, R. E. (1988). On the mechanics of economic development. Journal of monetary economics, 22(1), 3-42. https://doi.org/10.1016/0304-3932(88)90168-7

Lundvall, B. A. (2007). National innovation systems - analytical concept and development tool. Industry and innovation, 14(1), 95-119. https://doi.org/10.1080/13662710601130863

Malerba, F. (2002). Sectoral systems of innovation and production. Research policy, 31(2), 247-264. https://doi.org/10.1016/s0048-7333(01)00139-1

Martin, B. R. (2012). The evolution of science policy and innovation studies. Research policy, 41(7), 1219-1239. https://doi.org/10.1016/j.respol.2012.03.012

Mas-Tur, A., \& Soriano, D. R. (2014). The level of innovation among young innovative companies: the impacts of knowledge-intensive services use, firm characteristics and 
the entrepreneur attributes. Service Business, 8(1), 51-63.

https://doi.org/10.1007/s11628-013-0186-X

Mazzucato, M. (2015). Innovation systems: from fixing market failures to creating markets. Revista do Serviço Público, 66(4), 627-640.

McCain, K. W. (1990). Mapping authors in intellectual space: A technical overview. Journal of the American society for information science, 41(6), 433-443. https://doi.org/10.1177/009365089016005007

Mendonça, H. L., \& Fonseca, M. V. D. A. (2018). Working towards a framework based on mission-oriented practices for assessing renewable energy innovation policies. Journal of Cleaner Production, 193, 709-719. https://doi.org/10.1016/j.jclepro.2018.05.064

Minniti, M. (2008). The role of government policy on entrepreneurial activity: productive, unproductive, or destructive?. Entrepreneurship theory and Practice, 32(5), 779-790. https://doi.org/10.1111/j.1540-6520.2008.00255.x

Mintrom, M. (2013). Policy entrepreneurs and controversial science: Governing human embryonic stem cell research. Journal of European Public Policy, 20(3), 442-457. https://doi.org/10.1080/13501763.2012.761514

Moilanen, M., Østbye, S., \& Woll, K. (2014). Non-R\&D SMEs: external knowledge, absorptive capacity and product innovation. Small Business Economics, 43(2), 447462. https://doi.org/10.1007/s11187-014-9545-9

Pathak, S., Xavier-Oliveira, E., \& Laplume, A. O. (2013). Influence of intellectual property, foreign investment, and technological adoption on technology entrepreneurship. Journal of Business Research, 66(10), 2090-2101. https://doi.org/10.1016/j.jbusres.2013.02.035

Prasad, S., \& Tata, J. (2005). Publication patterns concerning the role of teams/groups in the information systems literature from 1990 to 1999. Information \& Management, 42(8), 1137-1148. https://doi.org/10.1016/j.im.2005.01.003

Podsakoff, P. M.; Mackenzie, S. B.; Bachrach, D. G.; Podsakoff, N. P. (2005). The Influence of Management Journals in the 1980s and 1990s. Strategic Management Journal, v. 26, n. 5, pp. 473-488. https://doi.org/10.1002/smj.454

Ramos-Rodríguez, A. R., \& Ruíz-Navarro, J. (2004). Changes in the intellectual structure of strategic management research: A bibliometric study of the Strategic Management Journal, 1980-2000. Strategic management journal, 25(10), 981-1004. https://doi.org/10.2307/20142173

Romer, P. M. (1986). Increasing returns and long-run growth. Journal of political economy, 94(5), 1002-1037. https://doi.org/10.1086/261420

Romer, P. M. (1990). Endogenous technological change. Journal of political Economy, 98(5, Part 2), S71-S102. https://doi.org/10.3386/w3210 
Schmitz, H., \& Altenburg, T. (2016). Innovation paths in Europe and Asia: Divergence or convergence?. Science and Public Policy, 43(4), 454-463. https://doi.org/10.1093/scipol/scv053

Schubert, C. (2015). What Do We Mean When We Say That Innovation and Entrepreneurship (Policy) Increase "Welfare"?. Journal of Economic Issues, 49(1), 1-22. https://doi.org/10.1080/00213624.2015.1013859

Serra, F. A. R., Ferreira, M. P., Guerrazzi, L. A. D. C., \& Scaciotta, V. V. (2018). Doing bibliometric reviews for the Iberoamerican Journal of Strategic Management. Iberoamerican Journal of Strategic Management, 17(03), 01-16. https://doi.org/10.5585/riae.v17i3.2713

Sherwood, A. L., \& Covin, J. G. (2008). Knowledge acquisition in university-industry alliances: An empirical investigation from a learning theory perspective. Journal of Product Innovation Management, 25(2), 162-179. https://doi.org/10.1111/j.15405885.2008.00292.x

Solow, R. M. (1956). A contribution to the theory of economic growth. The quarterly journal of economics, 70(1), 65-94. https://doi.org/10.2307/1884513

Thurik, A. R., Stam, E., \& Audretsch, D. B. (2013). The rise of the entrepreneurial economy and the future of dynamic capitalism. Technovation, 33(8-9), 302-310. https://doi.org/10.1016/j.technovation.2013.07.003

Uyarra, E., \& Flanagan, K. (2010). Understanding the innovation impacts of public procurement. European planning studies, 18(1), 123-143. https://doi.org/10.1080/09654310903343567

Visser, E. J., \& Atzema, O. (2008). With or without clusters: Facilitating innovation through a differentiated and combined network approach. European Planning Studies, 16(9), 1169-1188. https://doi.org/10.1080/09654310802401573

Vogel, R., \& Güttel, W. H. (2013). The dynamic capability view in strategic management: A bibliometric review. International Journal of Management Reviews, 15(4), 426-446. https://doi.org/10.1111/ijmr.12000

Walker, J. L. (1969). The diffusion of innovations among the American states. American political science review, 63(3), 880-899. https://doi.org/10.2307/1954434

Weisz, J. (2006). Mecanismos de apoio à inovação tecnológica. Brasília: SENAI/DN.

Willoughby, K. W. (2020). Endogenous innovation, outward-bound international patenting and national economic development. The Journal of Technology Transfer, 45(3), 844869. https://doi.org/10.1007/s10961-018-9705-1

Wonglimpiyarat, J. (2017). Tax and S\&T Policies for Research Commercialization: Perspectives of Southeast Asian Countries. International Journal of Innovation and Technology Management, 14(04), 1750017. https://doi.org/10.1142/S0219877017500171

Zupic, I., \& Čater, T. (2015). Bibliometric methods in management and organization. Organizational Research Methods, 18(3), 429-472. https://doi.org/10.1177/1094428114562629 